\title{
Syrphids feed on multiple patches in heterogeneous agricultural landscapes during the autumn season, a period of food scarcity
}

\author{
María Villa ${ }^{\mathrm{a}}$, Sónia A.P. Santos ${ }^{\mathrm{b}}$, Rosalina Marrão ${ }^{\mathrm{a}}$, Lara A. Pinheiro ${ }^{\mathrm{a}}$, \\ Jose Antonio López-Saez ${ }^{\mathrm{c}}$, António Mexia ${ }^{\mathrm{d}}$, Albino Bento ${ }^{\mathrm{b}}$, José Alberto Pereira ${ }^{\mathrm{a}, *}$ \\ a REQUIMTE-LAQV, School of Agriculture, Polytechnic Institute of Bragança, Campus Sta Apolónia, 5300-253 Bragança, Portugal \\ ${ }^{b}$ CIMO, School of Agriculture, Polytechnic Institute of Bragança, Campus Sta Apolónia, 5300-253 Bragança, Portugal \\ ' GI Arqueobiología, Instituto de Historia, CCHS, CSIC, Albasanz 26-28, 28037 Madrid, Spain \\ d Institute of Agronomy, University of Lisbon, Tapada da Ajuda, 1349-017 Lisboa, Portugal
}

A R T I C L E I N F O

\section{Article history:}

Received 2 October 2015

Received in revised form 7 September 2016

Accepted 13 September 2016

Available online 28 September 2016

\section{Keywords:}

Eupeodes corollae

Episyrphus balteatus

Non-crop vegetation

Olive grove

Mediterranean Europe

\begin{abstract}
A B S T R A C T
Many syrphid larvae are predators and have an important role as biological control agents of pests in agroecosystems. However, adults feed on non-prey resources such as pollen from flowers. Heterogeneous landscapes can provide syrphids with a great biodiversity of plants and ensure the existence of food resources. This is particularly important during periods of food scarcity, such as autumn, for syrphid species that spend those periods as adults. Nevertheless, the feeding habits of syrphid adults in resourcescarce agroecosystems are poorly known. In this study, the pollen consumption and preferences of Eupeodes corollae (Fabricius) and Episyrphus balteatus (De Geer) were analyzed in olive groves and surrounding herbaceous and woody patches in the autumns of 2012 and 2013 in northeastern Portugal. The guts were dissected, and the pollen types were identified and compared with the ground cover plants in the studied patches. Both species consumed and selected pollen types from herbaceous and woody vegetation that occurred in different patches, indicating that they flew between patches. These results highlight the importance of conserving heterogeneous agricultural landscapes to guarantee the existence of food resources for beneficial insects during periods of scarcity.
\end{abstract}

(c) 2016 Elsevier B.V. All rights reserved.

\section{Introduction}

Adult syrphids (Diptera: Syrphidae) require nectar as a source of carbohydrates for energy and pollen for the maturation of their reproductive system (Haslett, 1989a; Irvin et al., 1999; Lundgren, 2009; Schneider, 1948; Wratten et al., 1995), while larvae prey on aphids and the early stages of moths and psyllids, acting as natural control agents (Van Veen, 2010; Speight, 2011). Females need to feed on pollen to develop their eggs and to deposit yolk in the egg and therefore consume more pollen than males. Males need nectar for mate seeking, tissue maintenance and spermatogenesis and consume more nectar than females (Haslett, 1989a; Hickman et al., 1995; Irvin et al., 1999; Wratten et al., 1995).

Heterogeneous agricultural landscapes can positively influence syrphid abundance and diversity due to the occurrence of more diversified food items (flowering weeds, shrubs and trees) both in the crop field as well as in its surroundings. This contrasts with

\footnotetext{
* Corresponding author.

E-mail address: jpereira@ipb.pt (J.A. Pereira).
}

what occurs in more homogeneous agricultural landscapes or areas where vegetation has been removed by tillage or due to herbicide application (e.g., Cowgill et al., 1993; Haenke et al., 2009; Lövei et al., 1993; Sajjad and Saeed, 2010; White et al., 1995). In this context, the maintenance of heterogeneous areas is considered to be essential for conservation biological control of pests by syrphids and, in some cases, habitat manipulation leads to a reduction in infestation levels (e.g., White et al., 1995).

In the Mediterranean region, plants bloom mainly in the spring and become less abundant from the summer to winter seasons. Coinciding with plants blooming, syrphids are mainly active in the spring and remain in diapause during the rest of the year, usually as larvae but sometimes as adults (Schneider, 1948; Speight, 2011). It is likely for this reason that syrphid diversity and feeding behavior have been studied mainly during the spring and that few studies on pollen feeding habits have been carried out during seasons of flower scarcity, such as autumn (e.g., Burgio and Sommaggio, 2007; Hickman et al., 1995; Wratten et al., 1995). During diapause periods, if they feed, the energy obtained is used for catabolism and storage of material in the fat body (Schneider, 1948). Therefore, syrphid feeding behavior during low activity periods might be 
relevant for their development and maintenance, and understanding such behavior could bring new insights about habitat management to enhance syrphid performance.

Analyzing pollen grains within the gut of insects is one technique used to study plant feeding behavior (e.g., Holloway, 1976). Syrphid species mostly digest pollen grains through enzymes in the midgut, and afterward pollen exine remains visible (Gilbert, 1981; Haslett, 1983), which makes it possible to identify the pollen types consumed by syrphids through gut dissection. This technique has been used by different authors as a means for studying seasonal and gender-specific feeding patterns (Hickman et al., 1995; Irvin et al., 1999; Wratten et al., 1995).

One of the most important crops in Mediterranean-climate regions around the world is the olive tree, with a widespread distribution and a high socio-economic impact. In this crop, the larvae of syrphids have been found to feed on olive pests, such as the Lepidoptera Prays oleae (Bern.) (Praydidae) (Sacchetti, 1990; Silvestri, 1908) and Palpita vitrealis (Rossi) (Crambidae) and the Hemiptera (Psyllidae) Euphyllura olivina (Costa) (Ksantini, 2003) and Euphyllura straminea Loginova (Rojo et al., 2003). It has been suggested that an increase in plant species biodiversity may contribute to the regulation of pests and diseases (Ratnadass et al., 2012). Paredes et al. (2013) studied the influence that herbaceous and woody vegetation surrounding olive groves had on the natural enemies of olive pests (e.g., spiders, ants, predatory heteropterans and hymenopteran parasitoids); however, the foraging habits of adult syrphids are poorly known, and as far as we know, no study has been conducted in landscapes where the olive tree is dominant. Thus, the objective of this work was to identify the plant species exploited by syrphids as pollen sources in olive groves and the surrounding landscape during periods of flower scarcity. We tested whether syrphids preferentially consumed herbaceous or woody plants and if they exploited several patches surrounding agricultural areas to determine the importance of heterogeneous landscapes in supplying food resources for syrphids.

\section{Materials and methods}

\subsection{Study areas}

Field studies were conducted in the Mirandela municipality, northeastern Portugal, during 2012 and 2013 in three olive groves (Cedães: $41^{\circ} 29^{\prime} 16^{\prime \prime} \mathrm{N}, \quad-7^{\circ} 07^{\prime} 34^{\prime \prime} \mathrm{W}, \quad$ Paradela: $41^{\circ} 32^{\prime} 8^{\prime \prime} \mathrm{N}$, $-7^{\circ} 07^{\prime} 29^{\prime \prime} \mathrm{W}$, and Guribanes: $41^{\circ} 34^{\prime} 12^{\prime \prime} \mathrm{N},-7^{\circ} 09^{\prime} 59^{\prime \prime} \mathrm{W}$ ) and two surrounding field areas (an herbaceous vegetation patch and a scrubland) next to each olive grove. During the experimental years, the olive groves were not tilled and were not sprayed with pesticides.

The choice of study sites was based on the COS2007 (COS, 2010), which is currently the most updated map of land uses in continental Portugal. We selected the most frequent land uses occurring in the region: olive groves, scrubland patches that were composed of three vegetation strata (herbaceous, shrub and tree strata derived from agriculture abandonment) and herbaceous vegetation patches that were composed of cereal or grass mixtures for livestock feed. The three studied olive groves are approximately 2 ha in area and the surrounding patches are approximately 1 ha.

\subsection{Syrphid sampling and identification}

Five white delta traps with sticky cardboard and baited with $P$. oleae pheromone were installed $50 \mathrm{~m}$ apart in each herbaceous, scrubland and olive grove patch ( 45 traps in total) during the spring, summer and autumn of 2012 and 2013. Although these traps targeted monitoring the flight cycle of $P$. oleae, syrphids were also captured during the autumns of both years. Syrphid adults were collected from each delta trap in December 2012 and 2013, corresponding to the sampling period that occurred between September and December. The syrphid species were identified according to Van Veen (2010) and kept in 96\% alcohol until further analysis.

\subsection{Pollen analyses}

Each syrphid was washed in $96 \%$ alcohol to eliminate the external pollen. The abdomen was removed from the body and opened with the help of a scalpel, needles and fine forceps. The gut was released onto a glass slide, two drops of glycerin jelly:water (1:1) were added, and a coverslip $(22 \times 22 \mathrm{~mm})$ was applied. To prevent pollen contamination between the samples, the scalpel, needles and forceps were washed after each dissection. The pollen grains were counted and identified to pollen type using an optical microscope. Identification was based on Valdés et al. (1987) and Moore et al. (1991) and supported by a reference pollen collection hosted at the School of Agriculture, Polytechnic Institute of Bragança. When there were more than 5000 pollen grains, half of the slide was counted, and when there were more than 15,000, a quarter of the slide was counted; the total number of grains was estimated thereafter.

\subsection{Flowering plant inventories}

Five flowering plant inventories were carried out in circular plots of $25 \mathrm{~m}^{2}$ (olive groves and herbaceous patches) and three plots of $100 \mathrm{~m}^{2}$ (scrubland patches). The inventories were carried out around the installed delta traps. The plots were larger in the scrublands because the larger size of the plant species (trees and shrubs) required inventories to be conducted in larger plots to record the occurring plants. Therefore, the number of inventories in the scrublands was reduced to three around delta trap numbers 1,3 , and 5 . This resulted in a total of 39 plant inventories for characterizing the plant community of the olive grove agroecosystem. The inventories were conducted every other week from September to December in each patch and throughout both years. The percentage ground cover for each flowering plant species was recorded following the Daubenmire cover scale modified by Bailey (Mueller-Dombois and Ellenberg, 1974).

\subsection{Data analyses}

The association between syrphid species and the three patch types was analyzed using a contingency table. To determine if the pollen types found in the gut of syrphids were consumed at random or were preferentially consumed, a specific Z-test was applied following Villenave et al. (2006). It was calculated as $Z=(\bar{Y}-1) / \alpha$, where $\bar{Y}=$ the average $Y i$ for a particular pollen type and $\alpha=$ the standard error. $\mathrm{Y} i=$ the percentage of pollen type $i$ consumed by syrphids/the percentage of ground cover for the species producing pollen type $i$. Consumption is considered to be random when $-1.96<\mathrm{Z}<1.96$. This test is only valid if there are at least 15 observations. The difference between the total pollen grains consumed by females and males was analyzed using a MannWhitney $U$ test. The statistical analyses were performed with IBMSPSS statistics, version 19.0.0 (SPSS Inc., IBM Company, 2010).

\section{Results}

\subsection{Syrphid species diversity}

Eupeodes corollae (Fabricius) and Episyrphus balteatus (De Geer) were the most abundant species collected in the delta traps in both 
years. Other specimens belonging to seven species (Eupeodes luniger (Meigen), Eupeodes nielseni (Dusek and Laska), Sphaerophoria scripta (Linnaeus), Melanostoma mellinum (Linnaeus), Melanostoma scalare (Fabricius), Eristalis similis (Fallen) and Paragus sp.) were also captured. Because few specimens of these species were collected, pollen feeding habits could only be analyzed for $E$. corollae and $E$. balteatus. The abundance and distribution of the least collected species throughout the patches and years are provided as Supplemental material-Table A.1.

During the autumn of 2012, E. corollae was the most abundant species, representing $64.1 \%$ of the total number of specimens (herbaceous vegetation: 53 females and 59 males; scrubland: 14 females and 22 males; olive groves: 7 females and 4 males), followed by $E$. balteatus, representing $23.4 \%$ of the total number of specimens (herbaceous vegetation: 21 females and 29 males; scrubland: 8 males).

During the autumn of $2013, E$. balteatus was the most abundant species, representing $71 \%$ of the total number of specimens (herbaceous vegetation: 20 females and 29 males; scrubland: 2 males), followed by E. corollae, representing $9 \%$ of the total number of specimens (herbaceous vegetation: 3 females and 3 males; olive groves: 1 female).

In both years, the abundance of syrphids was highest in the herbaceous patches, followed by the scrublands and olive groves. The contingency table showed a statistically significant association between the patch type and both E. corollae and E. balteatus in 2012 and between the patch type and E. balteatus in $2013\left(\chi^{2}=19.66\right.$, $p<0.05, \mathrm{df}=4)$. In particular, E. balteatus was positively associated with herbaceous patches because it was more abundant there than expected.

\subsection{Plant diversity and ground cover}

The plant inventories carried out in each patch resulted in the identification of 52 flowering plant species belonging to 21 families, and they were grouped into 27 pollen types (detailed information is given as Supplemental material-Table A.2). In the scrublands, five species were identified and grouped into five pollen types in both autumn seasons. The most abundant was Arbutus unedo L. (Arbutus unedo pollen), followed by Daphne gnidium L. (Daphne gnidium type) and Foeniculum vulgare L. (Apiaceae pollen). In the herbaceous patches during 2012, 28 plant species were identified and grouped into 17 pollen types. Species belonging to the Cichorioideae subfamily dominated, namely Leontodon taraxacoides (Vill.) Mérat subsp. longirostris Finch and P. D. Sell, Hypochaeris radicata L. and Chondrilla juncea L. In 2013, 32 species were identified and grouped into 15 pollen types. The most abundant species was Conyza sumatrensis (Retz.) E. Walker (Cardueae pollen), followed by Hypochaeris glabra L. (Cichorioideae pollen) and Brassica barrelieri (L.) Janka (Brassicaceae pollen). In the olive groves in 2012, 14 species were identified and grouped into eight pollen types. The most abundant species was $C$. juncea, followed by Conyza bonariensis (L.) Cronq. (Cardueae) and $F$. vulgare. In 2013, 11 species were identified and grouped into seven pollen types. The most abundant species was $C$. juncea, followed by Capsella bursa-pastoris (L.) Medik. (Brassicaceae pollen) and F. vulgare.

In 2012, the herbaceous patches presented the highest percentage of ground cover (1.4\%), followed by olive groves $(0.5 \%)$ and scrublands $(0.4 \%)$. In 2013 , the herbaceous patches presented the highest percentage of cover (7.05\%), followed by scrublands (3.6\%) and olive groves (0.9\%). The total ground cover of flowering plants was higher in 2013 than in 2012. In the herbaceous patches, species belonging to Brassicaceae, Fabaceae and Amaranthaceae accounted for $48 \%$ of the increase in the total ground cover. The differences found in scrubland patches were principally due to the higher ground cover of $A$. unedo.

\subsection{Pollen types}

A total of 40 pollen types were found in the guts of syrphids. The number of pollen grains varied from approximately 10 to several thousands.

Considering $E$. corollae in 2012 , the number of pollen types found in each specimen varied from one to five (Fig. 1), and 24 pollen types were identified. The pollen types belonging to Asteraceae were the most represented, followed by Fabaceae, Corrigiola telephiifolia type, D. gnidium type and Ranunculaceae (Fig. 2). $65.3 \%$ of the 72 females and $67.1 \%$ of the 85 males contained pollen grains in their guts, but no significant differences were found $(Z=-0.325, p=0.745)$ between the total pollen grains or pollen types consumed by females and males. For 2013, a descriptive analysis is presented because only seven individuals were captured. The number of pollen types varied from one to seven, and three out of four females and the three males analyzed had pollen in their guts. Fourteen pollen types were found, with the most common belonging to Asteraceae, Ranunculaceae and Salix type.

For E. balteatus in 2012, the number of pollen types found in the guts of the specimens varied between one and seven (Fig. 1). Twenty pollen types were identified, with Asteraceae being the most abundant, followed by $D$. gnidium type, Fabaceae, Corrigiola type, Ranunculaceae and A. unedo (Fig. 3). 68.4\% of the 19 females and $63.9 \%$ of the 36 males contained pollen in their guts, and no differences were found $(Z=-0.027 ; p=0.978)$ between the total pollen grains consumed by females and males. In 2013, the number of pollen types found per specimen varied between one and 11 . Twenty-seven pollen types were identified in the guts of the analyzed $E$. balteatus, with Asteraceae being the most abundant pollen type, followed by Salix type, Ranunculaceae pollen, Cytisus/ Ulex type, $A$. unedo and D. gnidium type. $90 \%$ of the 20 females and $93 \%$ of the 31 males contained pollen grains in their guts, and no differences $(Z=-1.187 ; p=0.235)$ were found between the total pollen grains consumed by females and males.

Several specimens contained pollen types consumed in a different patch from that in which they were captured. Thus, in 2012, 60 out of the 112 E. corollae specimens collected in herbaceous patches consumed pollen types that were not represented in these patches as well as 20 out of the 36 specimens

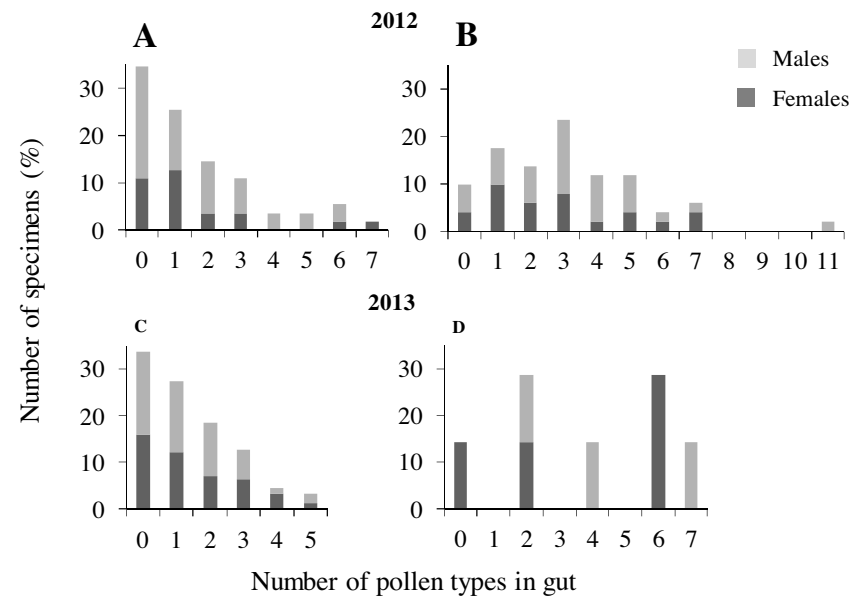

Fig. 1. Distribution of the number of different pollen types found in the guts of Episyrphus balteatus (A: 19 females and 36 males in 2012; B: 20 females and 31 males in 2013) and Eupeodes corollae (C: 72 females and 85 males in 2012; D: 4

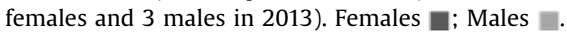




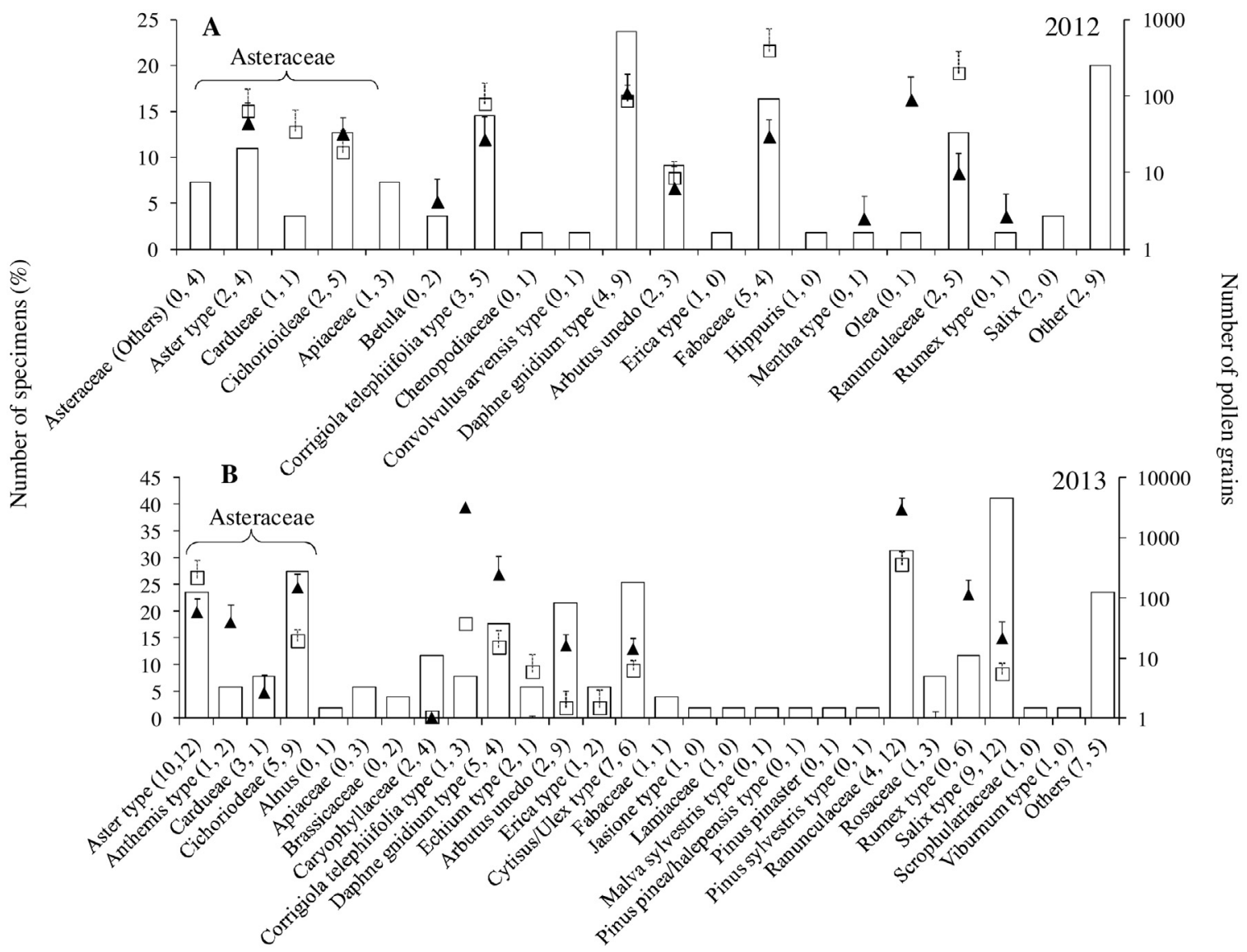

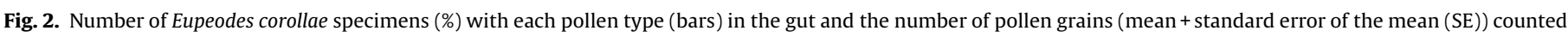

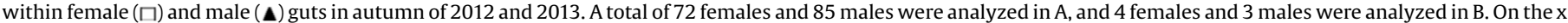

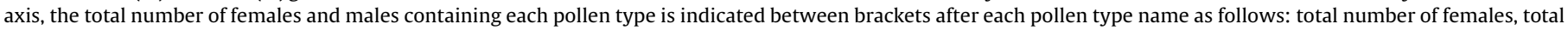
number of males.

collected in scrubland patches and 5 out of the 11 specimens collected in olive groves; for E. balteatus, 24 out of the 50 specimens collected in herbaceous patches consumed pollen in other patches as well as 2 out of the 8 specimens collected in scrubland. In 2013, 5 out of the 6 E. corollae specimens collected in herbaceous patches and 1 out of 1 collected in olive groves obtained pollen in other patches, while 42 out of the 49 E. balteatus specimens collected in herbaceous patches and 1 out of the 2 specimens collected in scrublands visited other areas.

\subsection{Pollen consumption and preference}

A Z-test was applied when more than 15 specimens were captured, i.e., E. balteatus in 2012 and 2013 and E. corollae in 2012. The Z-test values indicated that some pollen types were consumed at random $(-1.96<\mathrm{Z}<1.96)$ and some were preferred. Thus, $E$. balteatus preferred Aster type, C. telephiifolia type, D. gnidium type, Fabaceae pollen and Ranunculaceae pollen in 2012 and A. unedo, Cichorioideae pollen, Cytisus/Ulex type, Ranunculaceae pollen and Salix pollen in 2013. Although the Z-test indicated that Aster type, $D$. gnidium type and Cichorioideae pollen were selected only in one of the years, their Z-test values were always close to the selection value, and a considerable number of specimens contained them in their guts (Table 1 ).

In terms of E. corollae in 2012, the Z-test showed a preference for Apiaceae pollen, Aster type, unidentified Asteraceae, Caryophyllaceae pollen, Cichorioideae pollen, $C$. telephiifolia type, $D$. gnidium type and Fabaceae pollen (Table 1 ).

\section{Discussion}

Most arthropod species use not only the crop area but also surrounding non-crop habitats, and complex landscapes may enhance pest regulation (Tscharntke et al., 2007). This study suggests that syrphids flew among patches to forage, collecting pollen from multiple habitats, and indicates that feeding may be affected by the landscape. This is in agreement with the results obtained by Ouin et al. (2006), who showed that greater patch areas, connectivity, and habitat heterogeneity had positive effects on syrphid species richness. Moreover, Sarthou et al. (2005) found that landscape structure, the length of forest edges and most likely the presence of shrubs influenced the abundance of $E$. balteatus. Ricarte et al. (2011) also highlighted the need to focus on the conservation of woodland remnants in grassland-dominated and scrubland-dominated landscapes to preserve a large proportion of the biodiversity of syrphids in their studied areas and also emphasized the importance of maintaining the mosaic landscape. Additionally, landscape heterogeneity could favor other biocontrol agents, as shown by Koh and Holland (2015) for the predatory families of Anthocoridae, Nabidae and Coccinellidae and by Lefebvre et al. (2016) for the spider species Cheiracanthium mildei C. L. Koch, resulting in complementary action against pests.

The most abundant species collected in this study, E. balteatus and E. corollae, are widely distributed in Europe (Van Veen, 2010; Speight, 2011). Both are commonly related to open habitats (Branquart and Hemptinne, 2000; Rojo et al., 2003; Speight, 2011). Their flight period occurs from the beginning of spring until the 


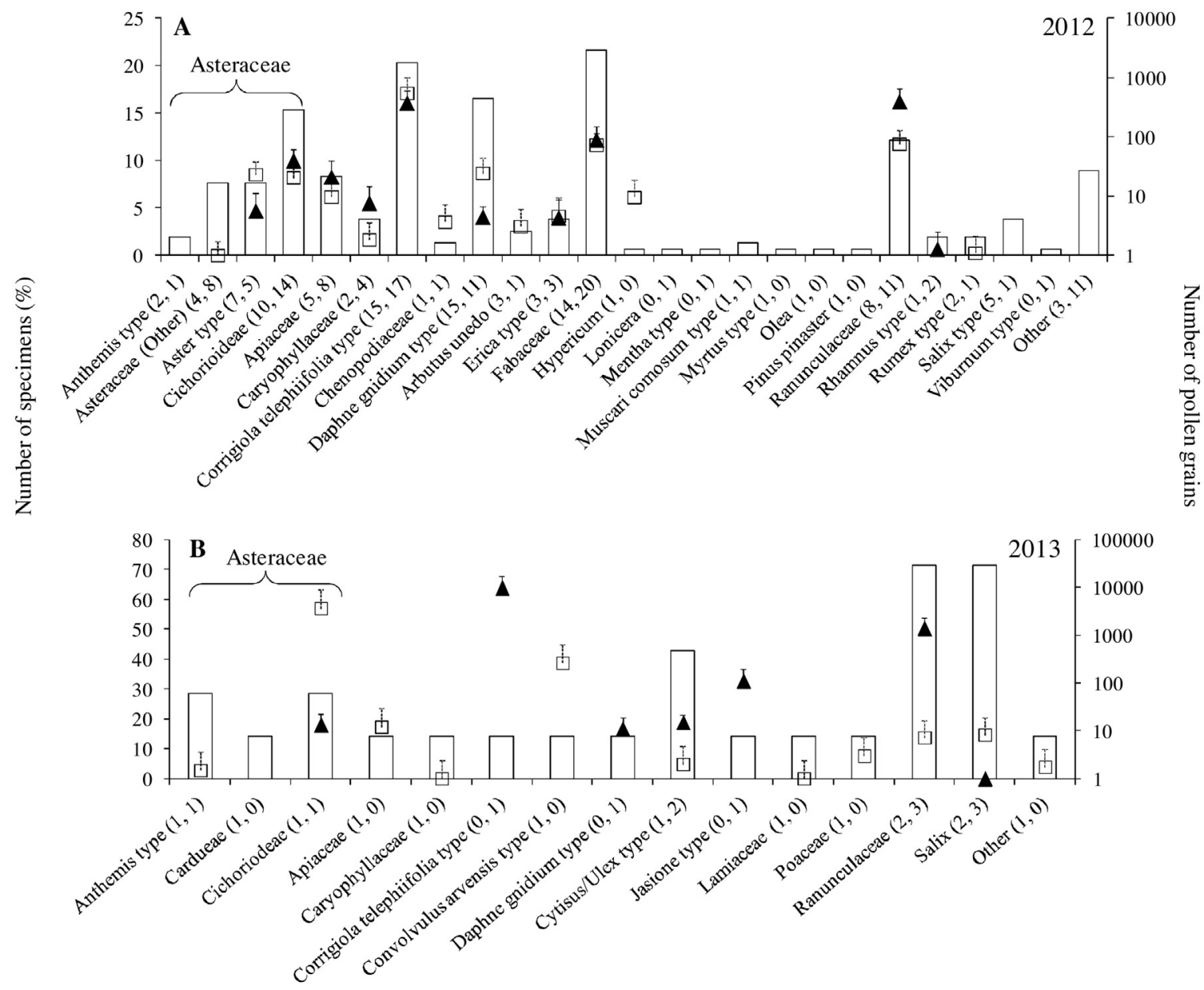

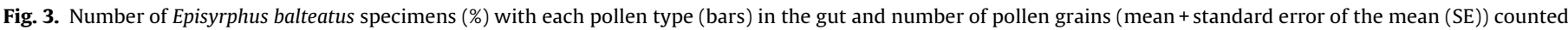

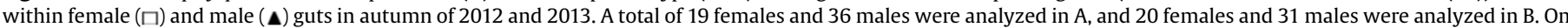

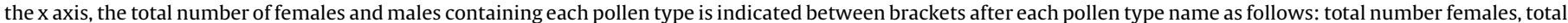
number males.

end of autumn, and they can overwinter as adults in some regions (Speight, 2011). In our work, a higher number of syrphids was also collected in open patches (herbaceous areas) than in woody patches (olive groves and scrublands). Moreover, E. balteatus was equally abundant in both years, while E. corollae was mainly found in 2012. This may indicate that the population of E. balteatus could be more stable and more resistant to adverse conditions than that of $E$. corollae. Additionally, few specimens were captured in olive groves in this season. Nevertheless, during spring, syrphids are easily observed hovering over flowers in olive groves. This could indicate the seasonal use of different types of patches by syrphids, with herbaceous and woody vegetation patches around the groves being selected during autumn.

Contrary to previous research conducted during spring (Haslett, 1989a), we found that the amount of pollen consumed by females in autumn did not differ from that consumed by males, most likely because energy is spent for tissue maintenance purposes and not for reproduction. Both $E$. balteatus and $E$. corollae fed on the pollen of different plant species, revealing a certain degree of selectivity for the pollen of herbaceous vegetation, such as Asteraceae, Ranunculaceae, and C. telephiifolia type, and that of woody vegetation, such as $A$. unedo, Cytisus/Ulex pollen type, $D$. gnidium type, and Salix, and, in the specific case of E. corollae, also the pollen of Apiaceae and Caryophyllaceae. The consumption of pollen is a result of the compatibility between floral morphology and the insect head and the structure of the mouthparts (Jervis and Heimpel, 2005), and these traits can influence plant selection by syrphids. According to Branquart and Hemptinne (2000), adults of the Syrphinae subfamily did not show strong flower preferences but exploited pollen and nectar produced by native plants with large inflorescences and flat corollas, e.g., Apiaceae, Asteraceae, Ranunculaceae and Rosaceae. Among other species, they found $E$. balteatus and $E$. corollae to be highly polyphagous, which is in agreement with our study. We also observed these species to be polyphagous. Additionally, they did not use all flowers available, selecting some pollen types. The fact that $E$. balteatus did not select the same pollen types in both years even though this species was equally abundant could be related to the variation in the vegetation that occurred in those years, which may have altered the ability of E. balteatus to select its preferred foods. As mentioned by Jervis and Kidd (1996), generalist flower-visitors can visit some flower types more frequently than would be expected on the basis of their relative abundance, and their preferences can be altered by different nutritional and environmental factors.

In this study, Asteraceae plants were commonly found in the herbaceous and olive grove patches, while they were less common in the scrublands. In E. balteatus and E. corollae guts, Aster pollen type and Cichorioideae pollen were the most abundant pollen 
Table 1

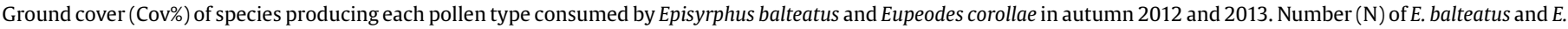

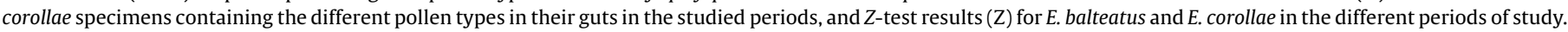
Consumption is considered at random when $-1.96<\mathrm{Z}<1.96$. Bold numbers indicate pollen types that were preferred by syrphid species.

\begin{tabular}{|c|c|c|c|c|c|c|c|c|}
\hline \multirow[t]{3}{*}{ Pollen type } & \multicolumn{5}{|l|}{2012} & \multicolumn{3}{|l|}{2013} \\
\hline & \multirow[b]{2}{*}{$\operatorname{Cov}(\%)$} & \multicolumn{2}{|c|}{ E. balteatus } & \multicolumn{2}{|c|}{ E. corollae } & \multicolumn{3}{|c|}{ E. balteatus } \\
\hline & & $\mathrm{N}$ & $\mathrm{Z}$ & $\mathrm{N}$ & $\mathrm{Z}$. & $\operatorname{Cov}(\%)$ & $\mathrm{N}$ & $\mathrm{Z}$ \\
\hline Alnus & & & & & & 0 & 1 & 1.000 \\
\hline Anthemis type & 0.009 & 4 & 1.410 & 3 & 1.220 & 0.036 & 3 & 1.060 \\
\hline Apiaceae & 0.069 & 4 & 1.500 & 13 & 2.764 & 0.098 & 3 & 0.380 \\
\hline Arbutus unedo & 0.105 & 5 & 1.180 & 4 & 1.511 & 1.000 & 11 & 2.060 \\
\hline Aster type & 0.013 & 6 & 2.070 & 12 & 2.959 & 0.007 & 12 & 1.850 \\
\hline Asteraceae (other) & & 4 & 1.550 & 12 & 2.507 & & & \\
\hline Betula & & 2 & 1.000 & & & & & \\
\hline Brassicaceae & & & & & & 0.559 & 2 & 28.920 \\
\hline Cardueae & 0.085 & 2 & 0.420 & & & 0.006 & 4 & 0.290 \\
\hline Caryophyllaceae & 0.002 & & & 6 & 2.061 & 0.013 & 6 & 1.430 \\
\hline Chenopodiaceae & & 1 & 1.000 & 2 & 1.000 & & & \\
\hline Cichoriodeae & 0.364 & 7 & 1.810 & 24 & 3.563 & 0.621 & 14 & 2.780 \\
\hline Convolvulus arvensis type & & 1 & 1.000 & & & & & \\
\hline Corrigiola telephiifolia type & & 8 & 2.650 & 32 & 5.290 & 0.002 & 4 & 1.790 \\
\hline Cytisus/Ulex type & & & & & & & 13 & 2.790 \\
\hline Daphne gnidium type & 0.025 & 13 & 2.820 & 26 & 3.574 & 0.156 & 9 & 1.760 \\
\hline Echium type & & & & & & 0.007 & 3 & 1.430 \\
\hline Erica type & & 1 & 1.000 & 6 & 1.756 & & 3 & 1.160 \\
\hline Fabaceae & 0.013 & 9 & 2.850 & 34 & 5.453 & 0.416 & 2 & 0.810 \\
\hline Hypericum & 0.005 & & & 1 & 1.000 & & & \\
\hline Hippuris & & 1 & 1.000 & & & & & \\
\hline Jasione type & & & & & & & 1 & 1.000 \\
\hline Lamiaceae & & & & & & & 1 & 1.000 \\
\hline Lonicera & & & & 1 & 0.999 & & & \\
\hline Malva sylvestris type & & & & & & & 1 & 1.000 \\
\hline Myrtus type & & & & 1 & 1.000 & & & \\
\hline Mentha type & 0.057 & 1 & 0.960 & 1 & 21.239 & & & \\
\hline Muscari comosum type & & & & 2 & 1.016 & & & \\
\hline Olea & & 1 & 1.000 & 1 & 1.000 & & & \\
\hline Pinus pinaster & & & & 1 & 1.000 & & 1 & 1.000 \\
\hline Pinus pinea/halepensis type & & & & & & & 1 & 1.000 \\
\hline Pinus sylvestris type & & & & & & & 1 & 1.000 \\
\hline Ranunculaceae & & 7 & 2.020 & 19 & 3.880 & & 16 & 3.980 \\
\hline Rhamnus type & & & & 3 & 1.404 & & & \\
\hline Rosaceae & & & & & & & 4 & 1.440 \\
\hline Rumex type & & 1 & 1.000 & 3 & 1.445 & & 6 & 1.640 \\
\hline Salix & & 2 & 1.000 & 6 & 2.279 & & 21 & 3.160 \\
\hline Scrophulariaceae & & & & & & & 1 & 1.000 \\
\hline Viburnum type & & & & 1 & 1.000 & & 1 & 1.000 \\
\hline $\mathrm{N}$ E. balteatus analyzed & 58 & & & & & 51 & & \\
\hline $\mathrm{N}$ E. balteatus with pollen & 36 & & & & & 46 & & \\
\hline N E. corollae analyzed & 157 & & & & & & & \\
\hline $\mathrm{N} E$. corollae with pollen & 104 & & & & & & & \\
\hline
\end{tabular}

types (Figs. 2 and 3) and were preferentially consumed in most cases (Table 1), indicating that they are important food resources for these syrphid species. In contrast, Anthemis pollen type and Cardueae pollen were less abundant in the guts (Figs. 2 and 3 ) and were consumed at random (Table 1). The plant species that produce these pollen types have been already shown in the literature to be consumed by E. balteatus and E. corollae (Lundgren, 2009 and references therein; Speight, 2011; Van Veen, 2010). Moreover, the Asteraceae species Chamaemelum nobile (L.) All. (Anthemis pollen type) and Crepis vesicaria L. (Cichorioideae pollen type) showed a positive effect on $E$. balteatus longevity in laboratory studies (Pinheiro et al., 2013).

Ranunculaceae and C. telephiifolia (in 2012) were preferentially consumed by syrphids, although they were not inventoried in any of the studied patches. Thus, the syrphids certainly visited other areas. E. corollae and E. balteatus were also found to feed on Ranunculaceae pollen by Cowgill et al. (1993) and Speight (2011).

In this study, Apiaceae and Caryophyllaceae pollen were preferentially consumed by E. corollae but not by E. balteatus.
Some Apiaceae and Caryophyllaceae species have been demonstrated to be attractive to syrphids (Bugg et al., 2008; Speight, 2011; Van Veen, 2010). Although Apiaceae pollen was consumed at random by $E$. balteatus, Laubertie et al. (2012) showed in a laboratory experiment that species such as Coriandrum sativum $\mathrm{L}$. can enhance $E$. balteatus reproduction.

In relation to woody species, although $E$. balteatus and E. corollae were captured in low numbers in the scrubland patches, they preferentially consumed shrub pollen (D. gnidium type, Cytisus/ Ulex type, A. unedo and Salix) independently of the patch in which they were captured. In 2013, we found that E. balteatus preferentially consumed Cytisus/Ulex type pollen, and some E. corollae consumed it at random. Our results are in agreement with Herrera (1988), who found both species visiting $D$. gnidium and $E$. corollae visiting Ulex minor Roth. (Cytisus/Ulex type), and with Speight (2011), who observed E. balteatus feeding on A. unedo flowers. Salix is cited as being important in the early spring and attractive to the first emerging syrphids (Van Veen, 2010), and $E$. corollae has been observed to feed on it (Speight, 2011). In the 
current work, syrphids preferentially consumed Salix, which was not present in the inventoried patches, showing that those specimens visited non-sampled areas.

Plant species belonging to Lamiaceae (e.g., Mentha suaveolens Ehrh.) and Brassicaceae (e.g., Raphanus raphanistrum L. and Brassica barrelieri (L.) Janka) were identified in all the patches but were consumed at random by E. balteatus and E. corollae. However, these families have been described to be attractive to syrphids (Bugg et al., 2008; Haslett, 1989b; Van Veen, 2010; Speight, 2011) and, in some cases, to have a positive effect on E. balteatus longevity (Pinheiro et al., 2013).

In the late summer, fewer plants are flowering, and the number of active syrphids decreases (Van Veen, 2010). Several reasons that may explain the syrphid captures in this study include the following: (1) The low abundance of flowers in association with the white color of the trap could have been a lure to syrphids, resulting in an abnormal number of specimens captured. This hypothesis is in agreement with Schneider (1969), who suggested that the attractiveness of traps to insects increases when the availability of surrounding flowers decreases. Likewise, Hickman et al. (2001) found hungry syrphids flying around yellow water traps. Additionally, Wratten et al. (1995) already found white traps to be attractive to some syrphid species. (2) Autumn weather (cold, wind and rain) may stimulate the search for shelter, with the shape of the delta traps being an appropriate refuge against adverse weather conditions. (3) Syrphids may be attracted by $P$. oleae pheromone; however, this is the least plausible explanation because during spring and summer periods, syrphids were abundant in the studied area, and delta traps that were already installed in the field captured very few specimens (Villa, personal observation). In other studies, Malaise and yellow sticky traps were common traps used to collect syrphids (Sommaggio, 1999); although delta traps have not been a usual method to collect syrphids, they captured a high abundance of specimens in this study.

In conclusion, it was found that syrphids fed on both herbaceous and woody vegetation, showing a preference for several plants and foraging in patches in the vicinities of the crop. Moreover, in seasons characterized by adverse weather conditions, these areas acted as overwintering sites. These results highlight the importance of conserving heterogeneous agricultural landscapes to ensure the occurrence of food resources and shelter for syrphids. Such observations could be a valuable asset because syrphids act as biological control agents in several agroecosystems. Therefore, this study is of major importance to determine which resources could contribute to improving and enhancing natural enemies in agricultural landscapes.

\section{Acknowledgements}

The authors are grateful to the Foundation for Science and Technology (Portugal) and COMPETE/QREN/EU for financial support through the research project EXCL/AGR-PRO/0591/2012: Olive crop protection in sustainable production under global climatic changes: linking ecological infrastructures to ecosystem functions and for grant SFRH/BD/70693/2010 awarded to M. Villa. The authors are also grateful to Carlos Aguiar for help with the plant species identification.

\section{Appendix A. Supplementary data}

Supplementary data associated with this article can be found, in the online version, at http://dx.doi.org/10.1016/j.agee.2016.09.014.

\section{References}

Branquart, E., Hemptinne, J.L., 2000. Selectivity in the exploitation of floral resources by hoverflies (Diptera: Syrphinae). Ecography 23, 732-742. doi: http://dx.doi.org/10.1111/j.1600-0587.2000.tb00316.x.

Bugg, R.L., Colfer, R.G. Chaney, W.E, Smith, H.A., Cannon, J. 2008. Flower Flies (Syrphidae) and Other Biological Control Agents for Aphids in Vegetable Crops. University of California. Division of Agriculture and Natural Resources. Publication 8285 .

Burgio, G., Sommaggio, D., 2007. Syrphids as landscape bioindicators in Italian agroecosystems. Agric. Ecosyst. Environ. 120, 416-422. doi:http://dx.doi.org/ 10.1016/j.agee.2006.10.021.

COS, 2010. COS2007: Carta de uso e ocupação do solo de Portugal Continental para 2007. Instituto Geográfico Português. Available at http://www.dgterritorio.pt/ cartografia_e_geodesia/cartografia/cartografia_tematica/ carta de ocupacao do solo cos_/cos 2007/ (accessed 01.08.16.).

Cowgill, S.E., Wratten, S.D., Sotherton, N.W., 1993. The effect of weeds on the numbers of hoverfly (Diptera: Syrphidae) adults and the distribution and composition of their eggs in winter wheat. Ann. Appl. Biol. 123, 499-515. doi: http://dx.doi.org/10.1111/j.1744-7348.1993.tb04922.x.

Gilbert, F.S., 1981. Foraging ecology of hoverflies: morphology of the mouthparts in relation to feeding on nectar and pollen in some common urban species. Ecol Entomol. 6, 245-262. doi:http://dx.doi.org/10.1111/j.1365-2311.1981.tb00612.x.

Haenke, S., Scheid, B., Schaefer, M., Tscharntke, T., Thies, C., 2009. Increasing syrphid fly diversity and density in sown flower strips within simple vs. complex landscapes. J. Appl. Ecol. 46, 1106-1114. doi:http://dx.doi.org/10.1111/j.13652664.2009.01685.x

Haslett, J.R., 1983. A photographic account of pollen digestion by adult hoverflies Physiol. Entomol. 8, 167-171. doi:http://dx.doi.org/10.1111/j.1365-3032.1983. tb00345.x.

Haslett, J.R., 1989a. Adult feeding by holometabolous insects: pollen and nectar as complementary nutrient sources for Rhingia campestris (Diptera: Syrphidae). Oecologia 81, 361-363. doi:http://dx.doi.org/10.1007/BF00377084.

Haslett, J.R., 1989b. Interpreting patterns of resource utilization: randomness and selectivity in pollen feeding by adult hoverflies. Oecologia 78, 432-433. doi: http://dx.doi.org/10.1007/BF00378732.

Herrera, J., 1988. Pollination relationships in southern Spanish Mediterranean shrublands. J. Ecol. 76, 276-287. doi:http://dx.doi.org/10.2307/2260469.

Hickman, J.M., Lövei, G.L., Wratten, S.D., 1995. Pollen feeding by adults of the hover fly Melanostoma fasciatum (Diptera: Syrphidae). N. Z. J. Zool. 22, 387-392. doi http://dx.doi.org/10.1080/03014223.1995.9518057.

Hickman, J.M., Wratten, S.D., Jepson, P.C., Frampton, C.M., 2001. Effect of hunger on yellow water trap catches of hoverfly (Diptera: Syrphidae) adults. Agric. Forest Entomol. 3, 35-40. doi:http://dx.doi.org/10.1046/j.1461-9563.2001.00085.x.

Holloway, B.A., 1976. Pollen-feeding in hoverflies (Diptera: Syrphidae). N. Z. J. Zool. 3, 339-350. doi:http://dx.doi.org/10.1080/03014223.1976.9517924.

Irvin, N.A., Wratten, S.D., Frampton, C.M., Bowie, M.H., Evans, A.M., Moar, N.T., 1999 The phenology and pollen feeding of three hover fly (Diptera: Syrphidae) species in Canterbury, New Zealand. N. Z. J. Zool. 26, 105115. doi:http://dx.doi. org/10.1080/03014223.1999.9518182

Jervis, M.A., Heimpel, G.E., 2005. Phytophagy. In: Jervis, M. (Ed.), Insects as Natural Enemies-A Practical Perspective. Springer, Dordrecht, pp. 525-550.

Jervis, M.A., Kidd, N.A.C., 1996. Phytophagy, In: Jervis, M.A., Kidd, N.A.C. (Eds.), Insect Natural Enemies. Practical Approaches to their Study and Evaluation. first ed Chapman \& Hall, Malaysia, pp. 375-394.

Koh, I., Holland, J.D., 2015. Grassland plantings and landscape natural areas both influence insect natural enemies. Agric. Ecosyst. Environ. 199, 190-199 org/ 10.1016/j.agee.2014.09.007.

Ksantini, M., 2003. Contribution à l'étude de la dynamique des populations du psylle de l'olivier Euphyllura olivina (Costa) (Homoptera - Sternorhyncha Aphalaridae) et de sa nuisibilité dans la région de Sfax. Dissertation. Sciences School of Sfax.

Lövei, G.L., Hodgson, D.J., MacLeod, A., Wratten, S.D., 1993. Attractiveness of some novel crops for flower- visiting hoverflies (Diptera: Syrphidae): comparisons from two continents. In: Corey, S., Dall, D., Milne, W. (Eds.), Pest Control and Sustainable Agriculture. CSIRO, Canberra, pp. 368-370.

Laubertie, E.A., Wratten, S.D., Hemptinne, J.L., 2012. The contribution of potential beneficial insectary plant species to adult hoverfly (Diptera: Syrphidae) fitness Biol. Control. 61, 1-6. doi:http://dx.doi.org/10.1016/j.biocontrol.2011.12.010.

Lefebvre, M., Fanck, P., Toubon, J.-F., Bouvier, J.-C., Lavigne, C., 2016. The impact of landscape composition on the occurrence of a canopy dwelling spider depends on orchard management. Agric. Ecosyst. Environ. 215, 20-29. doi:http://dx.doi. org/10.1016/j.agee.2015.09.003.

Lundgren, J.G., 2009. Relationships of Natural Enemies and Non-prey Foods. Springer Science+Business Media BV, Brookings.

Moore, P.D., Webb, J.A., Collinson, M.E., 1991. Pollen Analysis. Blackwell Scientific Publications, Oxford.

Mueller-Dombois, D., Ellenberg, H., 1974. Community sampling: the relevé method. Aims and Methods of Vegetation Ecology. John Wiley and Sons, USA, pp. 45-66.

Ouin, A., Sarthou, J.P. Bouyjou, B., Deconchat, M., Lacombe, J.P. Monteil, C., 2006. The species-area relationship in the hoverfly (Diptera, Syrphidae) communities of forest fragments in southern France. Ecography 29, 183-190. doi:http://dx doi.org/10.1111/j.2006.0906-7590.04135.x. 
Paredes, D., Cayuela, L., Campos, M., 2013. Synergistic effects of ground cover and adjacent vegetation on natural enemies of olive insect pests. Agric. Ecosyst. Environ. 173, 72-80. doi:http://dx.doi.org/10.1016/j.agee.2013.04.016.

Pinheiro, L.A., Torres, L., Raimundo, J., Santos, S.A.P., 2013. Effect of seven species of the family Asteraceae on the longevity and nutrient levels of Episyrphus balteatus. Biocontrol 58, 797-806. doi:http://dx.doi.org/10.1007/s10526-0139535-X.

Ratnadass, A., Fernandes, P., Avelino, J., Habib, R., 2012. Plant species diversity for sustainable management of crop pests and diseases in agroecosystems: a review. Agron. Sustain. Dev. 32, 273-303. doi:http://dx.doi.org/10.1007/s13593011-0022-4.

Ricarte, A., Marcos-García, M.A., Moreno, C.E., 2011. Assessing the effects of vegetation type on hoverfly (Diptera: Syrphidae) diversity in a Mediterranean landscape: implications for conservation. J. Insect. Conserv. 15, 865-877. doi: http://dx.doi.org/10.1007/s10841-011-9384-9.

Rojo, S., Gilbert, F.S., Marcos-García, M.A., Nieto, J.M., Mier, M.P., 2003. Revisión mundial de los sírfidos depredadores (Diptera, Syrphidae: Syrphinae) y sus presas. CIBIO Ediciones, Alicante.

SPSS Inc., IBM Company, 2010. IBM, SPSS Statistic for Windows, version 19.0.0. SPSS Inc., IBM Company, New York, USA.

Sacchetti, P., 1990. Observations on the activity and bioethology of the natural enemies of Prays oleae (Bern.) in Tuscany. I. Predators. Redia 73, 243-259.

Sajjad, A., Saeed, S., 2010. Floral host plant range of syrphid flies (Syrphidae Diptera) under natural conditions in southern Punjab, Pakistan. Pak. J. Bot. 42, 11871200.

Sarthou, J.P., Ouin, A., Arrignon, F., Barreau, G., Bouyjou, B., 2005. Landscape parameters explain the distribution and abundance of Episyrphus balteatus (Diptera: Syrphidae). Eur. J. Entomol. 102, 539-545. doi:http://dx.doi.org/ 10.14411/eje.2005.077.

Schneider, F., 1948. Beitrag zur kenntnis der generationsverhaltnisse und diapause rauberischer schwebfliegen. Mitteilungen der Schweizertschen Entomologischen Gesellschaft 21, 249-285.
Schneider, F., 1969. Bionomics and physiology of aphidophagous syrphidae. Ann. Rev. Ent. 14, 103-124. doi:http://dx.doi.org/10.1146/annurev. en.14.010169.000535.

Silvestri, F., 1908. La tignola dell'olivo (Prays oleellus Fabr.). Bollettino del Laboratorio di Zoologia Generale e Agraria della R. Scuola Superiore d'Agricoltura. Portici 2, 83-184.

Sommaggio, D., 1999. Syrphidae: can they be used as environmental bioindicators? Agric. Ecosyst. Environ. 74, 343-356. doi:http://dx.doi.org/10.1016/S0167-8809 (99)00042-0.

Speight, M.C.D., 2011. Species Accounts of the European Syrphidae (Diptera), Glasgow. Syrph the Net, the database of European Syrphidae, Syrph the Net Publications, Dublin.

Tscharntke, T., Bommarco, R., Clough, Y., Crist, T.O., Kleijn, D., Rand, T.A., Tylianakis, J. M., van Nouhuys, S., Vidal, S., 2007. Conservation biological control and enemy diversity on a landscape scale. Biol. Control. 43, 294-309. doi:http://dx.doi.org/ 10.1016/j.biocontrol.2007.08.006535.

Valdés, B., Diez, M.J., Fernandez, I., 1987. Atlas polínico de Andalucía occidental. Instituto de Desarrollo Regional. University of Sevilla, Sevilla.

Van Veen, M.P., 2010. Hoverflies of Northwest Europe. Identification Keys to the Syrphidae. KNNV Publishing, Utrecht.

Villenave, J., Deutsch, B., Lodé, T., Rat-Morris, E., 2006. Pollen preference of the Chrysoperla species (Neuroptera: Chrysopidae) occurring in the crop environment in Western France. Eur. J. Entomol.103, 771-777. doi:http://dx.doi. org/10.14411/eje.2006.104.

White, A.J., Wratten, S.D., Berry, N.A., Weigmann, U., 1995. Habitat manipulation to enhance biological control of Brassica pests by hover flies (Diptera: Syrphidae). J. Econ. Entomol. 88, 1171-1176. doi:http://dx.doi.org/10.1093/jee/88.5.1171.

Wratten, S.D., White, A.J., Bowie, M.H., Berry, N.A., Weigmann, U., 1995. Phenology and ecology of hover flies (Diptera: Syrphidae) in New Zealand. Environ. Entomol. 24, 595-600. doi:http://dx.doi.org/10.1093/ee/24.3.595. 